\title{
Raised Red Cell Distribution Width as a Prognostic Tool for Acute Aluminium Phosphide Poisoning (AALPP) Patients
}

\author{
Authors \\ Dr Akshay Surana, Dr Sachin Sharma \\ Corresponding Author \\ Dr Akshay Surana \\ Email: asurana06@yahool.com 7741906945 \\ Curewell Hospital Pvt. Ltd 19\1-C New Palasia Indore MP
}

\begin{abstract}
Objectives \& Aims: Identify the acute aluminium phosphide poisoning. Identify the acute aluminium phosphide poisoning induced changes in hematological parameters .Raised red cell distribution used as a prognostic tool for acute aluminium phosphide poisoning. The changed hematological parameter used as a survival index of acute aluminium phosphide poisoning patients.

Material \& Methods: Blood was collected in a sterile EDTA containing tube and processed following our established ISO certified hospital laboratory protocol .A complete blood counting including HB\%,PCV, Red cell indices ,platelet count and total white cell count and differential was done by Automated blood cell counter with peripheral blood smear examination and further confirmed by manual oil immersion smear study method. Peripheral smears study was done with field A and B stain and leishman stain.

Conclusion: Aluminium phosphide poisoning caused changes in size of peripheral red blood cell due to lipid per oxidation and oxidative stress of cell membrane. These oxidative stress and lipid per oxidations lead to damage the cell membrane of $R B C$. These damage directly related with severity of exposer of the Aluminium phosphide. This type of damages decided the outcome survival of patients. So variable size of $R B C$ occurs in peripheral blood used as a prognostic tool for severity of toxicity, monitoring of patients ,follow-up and outcome survival in the form of RDW.The RDW is a hematological parameter is easily generated by all type of hematological cell counters used as a good prognostic tool for acute aluminium phosphide poisoning

Keyword: aluminium phosphide poisoning, Red cell distribution width.
\end{abstract}

\section{Material \& Methods}

Study area and design- This present study was conducted at the Department of Pathology curewell hospital Pvt Ltd Indore MP. The study was designed as a observational hospital based study over a period of time from 2011 to 2016 years.

Ethical Consideration- Blood was collected in a sterile EDTA containing tube and processed following our established laboratory protocol then generate the report of each patient. Take informed consent was obtained from all study participant for use of your blood sample for medical research after doing physician request investigating and generate the report.

Patient's Selection Criteria- The study target all the acute aluminium phosphide poisoning toxicity patients on the basis of clinical signs, 
symptoms history of exposure, history by attainder and smell with residual element on cloth of patients. We include both emergency and IPD patients with all age groups, male and female both gender for study. Sample size is 100 patients.

Laboratory investigations Blood was collected in a sterile EDTA containing tube and processed following our established laboratory protocol. A complete blood counting including $\mathrm{HB} \%$, PCV, Red cell indices, platelet count and total white cell count and differential was done by Automated blood cell counter and peripheral blood smear examination. The all cell count indices including RBC, WBC count with differential along with morphological changes further confirmed by manual oil immersion smear study method. Peripheral smears study was done with field A and B stain and leishman stain.

\section{Red Cells Distribution Width and Peripheral Smear \\ Materials}

Purple vacutainer tube or capillary collector (EDTA) ethylenediaminetetraacetate, Slides and blue capillary tube, Needle or lancet, Vacutainer holder, Alcohol swab, Cotton balls, Absorbent materials, Slide case and heamatological cell counter.

\section{Procedure}

1. Specimen is collected into EDTA (purple) vacutainer. ( 5 or $7 \mathrm{ml}$ volume)

Step 1. A small drop of venous blood is placed on a glass microscope slide, using a glass capillary pipette.

Step 2. A spreader slide is positioned at $45^{\circ}$ angle and slowly drawn toward the drop of blood.
Step 3. The spreader slide is brought in contact with the drop of blood and is being drawn away.

Step 4. The spreader slide is further pulled out, leaving a thin layer of blood behind.

Step 5. The blood smear is nearly complete.

Step 6. End result will be a glass slide with a wellformed blood film. After drying for about 10 minutes, the slide is fixed in methanol \& stained with field A and B stain.

Then the run the sample in hematological cell counter and generate RDW data.

Red cell distribution width (RDW) is a red blood cell parameter that measures variability of red cell volume/size (anisocytosis). Depending on the types of hematology analyzer instruments, RDW can be reported statistically as coefficient of variation $(\mathrm{CV})$ and/or standard deviation (SD), RDW-CV and/or RDW-SD, respectively.

RDW-SD (express in fL) is an actual measurement of the width of the RBC size distribution histogram and is measured by calculating the width (in fL) at the $18-20 \%$ height level of the RBC size distribution histogram.

RDW-CV (express in \%) is calculated from standard deviation and $\mathrm{MCV}$

RDW-CV $(\%)=1$ standard deviation of RBC volume/MCV x $100 \%$.

$$
\begin{array}{ll}
\text { - } & \text { RDW-SD 39-46 fL } \\
\text { [1] } \\
\text { RDW-CV 11.6-14.6\% in adult }
\end{array}
$$

\section{Observation \& Discussion}

Acute aluminium phosphide poisoning toxicity induced RBC morphological changes lead to raised RDW.

Acanthocytes, echinocytes, shistocytes dacrocytes. and degenerated rbc they are all type changes occure in rbc population.

\begin{tabular}{|c|c|c|c|}
\hline RDW-CV & Prognosis & $\begin{array}{c}\text { Survival outcome of } \\
\text { patients }\end{array}$ & $\begin{array}{c}\text { Sample size } \\
\text { N=100 }\end{array}$ \\
\hline$>25$ to $<30 \%$ & Mild toxicity & Good & 62 \\
\hline$>30$ to $<36 \%$ & Moderate Toxicity & Average & 23 \\
\hline$>36$ to $<40 \%$ & Sever Toxicity & Poor & 12 \\
\hline$>40 \%$ & Marked Toxicity & Worst & 03 \\
\hline
\end{tabular}




\section{Result}

Univariate analysis showed that there were significant associations of high RDW values with, the acute aluminium phosphide poisoning , mild to marked type toxicity these various morphological changes cause the raised red cell distribution width use as a prognostic tool for survival index outcome of patients. Kruskal-Wallis tests revealed an association of raised RDW values with severity survival index patients: $p<0.0001$, survival prognostic index of patients with higher RDW values had poorer worst prognoses than those with normal RDW values (Wilcoxon test: $p=0.002$ ). multivariate analysis showed higher RDW is a significant prognostic factor $(p=0.040)$.

WBC also shows changes but not use as a prognostic tool because all chages are uniform degenerative changes.

\begin{tabular}{|l|l|}
\hline WBC cells & WBC Changes \\
\hline $\begin{array}{l}\text { Neutrophils and } \\
\text { Eosinophils }\end{array}$ & Degeneration \\
\hline Lymphocyte & $\begin{array}{l}\text { Degeneration or deformed } \\
\text { morphology }\end{array}$ \\
\hline Monocytes & $\begin{array}{l}\text { Nuclear under goes } \\
\text { disintegration,fragmentation } \\
\text { and cytoplamic vaculation . }\end{array}$ \\
\hline
\end{tabular}

Platelets shows aggregates at place only not any other specific pathology and not use as a prognostic tool.

Red cell morphological changes 40x and oil immersion.

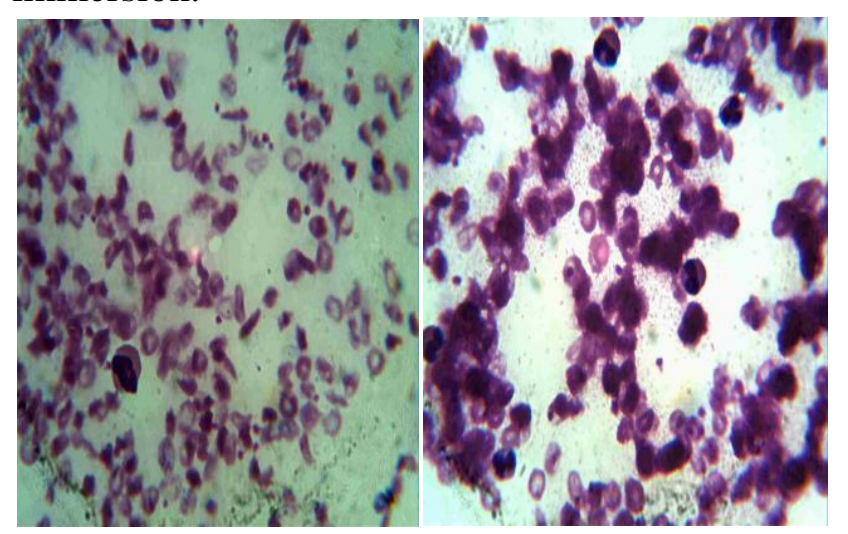

\section{Conclusion}

In this study, we found patients of aluminium phosphide toxicity shows various type RBC morphological degenerative changes ${ }^{5,6,7,15}$ on peripheral blood smear have mild to marked type toxicity these various morphological changes cause the raised red cell distribution width use as a prognostic tool for survival index outcome of patients. Slow or fast recovery, worst prognosis with very poor or delay recovery from illness is depend on RDW. RBC shows various ${ }^{8,12}$ types changes theses may be used as a prognostic tool ${ }^{5,4}$ for severity of toxicity, monitoring of patients and follow up of patients. WBC also shows changes but not use as a prognostic tool because all changes are uniform degenerative changes. All these type degeneration of all peripheral blood cells are due to to lipid per oxidation and oxidative stress ${ }^{4}$ of cell membrane.

\section{References}

1. Briggs C, Bain BJ. Basic Haematological Techniques. Bain BJ, Bates I, Laffan M, Lewis SM. Dacie and Lewis Practical Haematology. 11th ed. Philadelphia, PA: Churchill Livingstone/Elsevier; 2012. chap 3.

2. Vajpayee N, Graham SS, Bem S. Basic Examination of Blood and Bone Marrow. McPherson RA, Pincus MR. Henry's Clinical Diagnosis and Management by Laboratory Methods. 22nd. Elsevier/ Saunders: Philadelphia, PA; 2011. 30.

3. Sungurtekin H, Gurses E, Balci C. Evaluation of several clinical scoring tools in organophosphate poisoned patients. Clin Toxicol 2006; 44: 121-6.

4. Vidyasagar J, MS, Rajnarayana K, Surender T, Krishna DR. Oxidative stress and antioxidant status in acute organophosphorous insecticide poisoning. Indian J Pharmacol 2004; 36: 76-9.

5. Kaya A, Isik T, Kaya Y, Enginyurt O, Gunaydin ZY, Iscanli MD, et al. Relationship between red cell distribution width and stroke in patients with stable chronic heart failure: a propensity score matching analysis. Clin Appl Thromb Hemost 2013

6. Montagnana M, Cervellin G, Meschi T, Lippi G. The role of red blood cell 
distribution width in cardiovascular and thrombotic disorders. Clin Chem Lab Med 2011; 50: 635-41.

7. Şenol K, Saylam B, Kocaay F, Tez M. Red cell distribution width as a predictor of mortality in acute pancreatitis. Am J Emerg Med 2013; 31: 687-9.

8. Elsharkawy EE, Yahia D, El-Nisr NA. Sub-chronic exposure to chlorpyrifos induces hematological, metabolic disorders and oxidative stress in rat: attenuation by glutathione. Environ Toxicol Pharmacol 2013; 35: 218-27.

9. Ranjbar A, Pasalar P, Abdollahi M. Induction of oxidative stress and acetylcholinesterase inhibition in organophosphorus pesticide manufacturing worker. Hum Exp Toxicol 2002; 21: 179-82

10. Trevisan R, Uliano-Silva M, Pandolfo P, Franco JL, Brocardo PS, Santos AR, et al. Antioxidant and acetylcholinesterase response to repeated malathion exposure in rat cerebral cortex and hippocampus. Basic Clin Pharmacol Toxicol 2008; 102: 365-9.

11. Soltaninejad K, Abdollahi M. Current opinion on the science of organophosphatepesticides and toxic stress: a systematic review. Med Sci Monit 2009; 15: RA75-90

12. Bhatti GK, Bhatti JS, Kiran R, Sandhir R. Biochemical and morphological perturbations in rat erythrocytes exposed to ethion: protective effect of vitamin E. Cell Mol Biol 2011; 57: 70-9.

13. Ambali SF, Abubakar AT, Shittu M, Yaqub LS, Anafi SB, Abdullahi A. Chlorpyrifos-induced alteration of hematological parameters in Wistar rats: ameliorative effect of zinc. Res J Environ Toxicol 2010; 4: 55-66.

14. Edem VF, Akinyoola SB, Olaniyi JA, Rahamon SK, Owoeye O, Arinola OG. Haematological parameters of wistar rats exposed to 2,2 dichlorovinyl dimethyl phosphate chemical. Asian J Exp Biol Sci 2012; 3: 838-41.

15. Goel A, Dani V, Dhawan DK. Role of zinc in mitigating the toxic effects of chlorpyrifos on hematological alterations and electron microscopic observations in rat blood. Biometals 2006; 19: 483-92. 